\title{
EFFICIENCY OF WHEAT PRODUCTION IN REPUBLIC OF SERBIA
}

\author{
Rade Popovićl, Mina Kovljenic ${ }^{2}$
}

\section{Summary}

Wheat is one of the most important cereal and it is considered primarily as a source of energy (carbohydrate), in human diet. In Serbia, the most farms producing crops, where wheat is one of the most important crop. The paper investigates differences in efficiency of wheat production among Serbian farms with objective to identify the most efficient farms and possibilities for further improvement. Data for 2015/2016 production year are gathered through questionnaire during farms visit. In the paper non-parametric models of Data Envelopment Analysis (DEA) was used to identify differences in efficiency of wheat production among farms. The results reveal importance of farm size, size of plots and investments in the new machinery.

Key words: wheat, farms, efficiency, DEA.

JEL: $Q 12, Q 15$

\section{Introduction}

Today by far the most important food source in the world continue to remain cereals, contributing 50 percent of calories and as much as 54 percent in group of developing countries. Their contribution to energy intake varies markedly between developing and industrial countries. In developing countries such as in Africa and parts of Asia, cereals can contribute as much as 70 percent of energy intake. While in industrial countries, for example, the UK, cereals provide approximately 30 percent of energy intake and 50 percent of available carbohydrates. Projecting to 2050, it is expected that the share of cereals in calories for food use will continue to decline slowly from 54 percent in 2001 to 49 percent in 2030 and 46 percent in 2050 (Alexandratos, 2006). Of course, it does not mean decrease in production of cereals, but oppositely. On demand side, expected increase of population for $30 \%$ will be followed by $70 \%$

1 Rade Popović, Ph.D., Associate Professor, Department for Agricultural Economics and Agribusiness, Faculty of Economics Subotica, Segedinski put 9-11, 24000 Subotica, Phone: +381638041301, E-mail: popovicr@ef.uns.ac.rs

2 Mina Kovljenić M.A., Ph.D. Student of Economy, Faculty of Economics Subotica, Segedinski put 9-11, 24000 Subotica, Phone: +381645440106, E-mail: mina.sk90@yahoo.com

EP 2017 (64) 4 (1499-1511) 
increase of food demand (Rutten, 2012). On production side, process of slowing growth in yields has been going on for a longer period of time so that in the future expects to projected growth rates of return will be lower than half the actual historical growth rate (Lovre, Gajic, Kresoja, 2011).

The capacity of available resources and technologies that should meet the demands of a growing population for food and other agricultural products remains uncertain. Therefore, certain innovations are needed in agriculture, environmental protection and macroeconomic policy, at both national and international levels, in developed and especially in developing countries.

Wheat is the most important cereal on international market. As a global commodity, amount of wheat traded at international market reached 180 million tons in 2016 (USDA, 2017). Wheat is often considered primarily as a source of energy (carbohydrate) and it is certainly important in this respect. However, it also contains significant amounts of other important nutrients including proteins, fiber, and minor components including lipids, vitamins, minerals, and phytochemicals which may contribute to a healthy diet (Shewry, Hey, 2015). It provides $20 \%$ of the calories to the world's population and a similar proportion of daily protein for about 2.5 billion people in less-developed countries. If we look at its contribution to overall consumption of cereals, wheat provides about $41 \%$ of the calories and $50 \%$ protein (Shiferaw et al., 2013). The future productivity of wheat will arguably have more influence on global food security, than that of any other crop, because it is the most widely grown. Wheat is being adapted to a broad range of latitudes, temperatures, water regimes and nutritional levels (Reynolds et al., 2012).

In the Republic of Serbia wheat is one of the two leading plant products according share in sowing area and amount of production. In sowing structure wheat occupies 0.6 million hectares, with average production over 2 million tons per year during last decade. Regionally distribution of wheat production is more focused on North Serbia where farms have bigger average acreage. Thanks to good weather conditions in 2016 Serbia reached record wheat production in recent history. Although acreage planted by wheat was stable, strong increase in average yield pushed production up to 2.9 million tons (RZS, 2017).

Serbia is a net exporter of wheat. During the last decade from 2007 to 2016 net export of wheat and products from wheat varied from 0.2 to 1.2 million tons, depending on production. The leading export markets for Serbian wheat and products from wheat are: Romania, Bosnia and Herzegovina, Macedonia, Montenegro and Albania (RZS, 2017).

In recent years area of corn increased at the expense of reducing the area under wheat in the total planted area, due to reduced prices of wheat. In 2016, wheat prices ranged from $15.2 \mathrm{din} / \mathrm{kg}$, to $16.20 \mathrm{din} / \mathrm{kg}$ with VAT for standard quality, delivered to 
the buyer. Just year ago price of wheat in 2015 was $20.13 \mathrm{din} / \mathrm{kg}$ (18.30 excluding VAT) (Produktna berza, 2016). Higher corn prices relative to wheat caused a higher demand for wheat for production of animal food, as a substitute for corn.

According to the Census of Agriculture in 2012, in Serbia 99.5\% farms are individually owned, and they use $84 \%$ of the total arable land area. The average size of the farms owned by individuals is 4.5 ha, and the size varies considerably by regions 2.1 ha in the Jablanicki county, to 10.0 ha in Srednjebanatski county. The remaining $0.5 \%$ of farms are held by the legal entities, and they use $16 \%$ of the arable land and have an average size of the 210 ha per farm (Strategija, 2014).

In Serbia every second farm producing wheat. Production is well distributed among all types of farms size. Small farms with up to 8,000 EUR of Standard output (SA) produce wheat on $33.4 \%$ of total area under wheat. Middle size with 8,000 to 25,000 EUR of SA produce wheat on $22.4 \%$, and big farms plant wheat rest of $44.2 \%$ hectares (RZS, 2017).

The importance of individual farms is large, however, the economic importance of these holdings is at odds with their potential opportunities. This is because they are mostly small and without adequate support from the state for an extended period of time. Family labour carries out the work on the farm, which results in reduced employment potential. Nevertheless, these farms operate mainly within the limits of simple reproduction, with pronounced elements of natural and simple commodity production (Jelic, Jovanovic, 2004). Farm size is crucial for the efficiency of operations in agriculture, so one can conclude that with such unfavorable size farms hard to be competitive in the market and in terms of increased competition (Muncan, Todorovic, Muncan, 2014). Total production of wheat depends primarily on the area planted and the average yield of bread grain. Sowing areas of wheat vary from year to year, as a result of farmers profit expectation, market position etc.

On small farms with fragmented holdings and the existing structure of production, there are high production costs and inefficient use of resources, with the inability to achieve an efficient use of land. In addition, the average farm in Serbia is characterized by a low level of technical - technological equipment, an extremely small number of livestock per unit of agricultural land, and other indicators that make it difficult to increase productivity and profitability in production. Low productivity in the production has a negative impact on the price competitiveness of production and brings the average agricultural producer in a difficult position in the market (Nestorov-Bizonj, Kovljenic, Erdelji, 2015).

The purpose of this paper is to discover efficiency differences between wheat production among farms in North Serbia region. The goal of the paper is to discover the most efficient farms using the combination of inputs that minimises the cost of producing a given level of output, from an economic standpoint. 


\section{Literature review}

Many economic production models have been developed to estimate efficiency of farms and identify efficiency determinants. One of these models is nonparametric estimation named Data Envelopment Analysis - DEA. DEA constructs a nonparametric frontier over data points, so that all observations lie on or below the frontier (Laturffe et al., 2005).

There are input-orientated DEA model and output-oriented DEA model. Inputoriented technical efficiency measures address the question: "By how much can input quantities be proportionally reduced without changing the output quantities produced?" While output-oriented technical efficiency measures trying to answer question: "By how much can output quantities be proportionally expanded without altering the input quantities used?" (Coelli et al., 2005).

Farrell (1957) described two components of efficiency: technical efficiency (TE) and allocative efficiency (AE) or price efficiency. Technical efficiency reflects the ability of firm to obtain maximal output from a given set of inputs. Allocative efficiency reflects the ability of a firm to use the inputs in optimal proportions. Technical and allocative efficiency are then combined to provide a measure of total economic efficiency.

Two types of DEA model are in use: model with constant returns to scale (CRS) and model with variable returns to scale (VRS). The CRS assumption is appropriate when all firms are operating at an optimal scale. CRS is a strong assumption. In practice, production processes often do not scale perfectly, showing instead increasing returns to scale (IRS) and decreasing returns to scale (DRS) at various points (Rouse, Harrison, Chen, 2010). Imperfect competition, government regulations, constraints on finance, etc., may cause a firm to be not operating at optimal scale (Coelli et al., 2005). Non-constant returns to scale are referred to as variable returns to scale (VRS). The VRS frontier envelops the farms more tightly than the CRS frontier. Consequently, farms that are inefficient under CRS can have higher estimated TE scores under VRS. Since VRS takes size into account, a farm is compared to other farms of similar size and hence may not have the same benchmarks as under CRS (Rouse, Harrison, Chen, 2010).

As a method DEA has been widely applied to evaluate the performance of many different types of organizations performing a variety of activities, including both profit and nonprofit organizations, at micro and macro level (Popovic, Djokic, Kleut, 2015).

Reig-Martınez and Picazo-Tadeo (2004), used Data Envelopment Analysis as an appropriate analytical tool to explore the possibilities of short-term viability of individual Spanish citrus farms, after eliminating current inefficient practices. 
They computed an overall efficiency measure and several indicators of short-run competitiveness that compare the ability of farms to generate net income under both current and efficient production plans. Their results show that there is a substantial fall in the number of farms judged economically non-viable after inefficiency has been removed.

Gerdessen and Pascucci (2013) paper shows how DEA can be used to address the issue of sustainability of 252 European agricultural systems. One CRS model and two VRS models were used to partition the regions into a subset of efficient and a subset of non-efficient regions. Inputs and outputs were defined based on the multidimensional perspective of sustainability and its three dimensions: economic, social, and environmental. Impact of model choices such as CRS versus VRS, input versus output orientation, and balancing constraints was shown in the paper.

Speelman et al. (2008) used data envelopment analysis (DEA) techniques to compute farm-level technical efficiency measures and sub-vector efficiencies for water use. It was shown that under constant returns to scale (CRS) and variable returns to scale (VRS) specification, substantial technical inefficiencies, of $49 \%$ and $16 \%$, respectively, exist among farmers. Farm size, landownership, fragmentation, the type of irrigation scheme, crop choice and the irrigation methods applied showed a significant impact on the sub-vector efficiency for water.

Laturffe et al. (2005) were analyzing efficiency differences of Polish livestock and crop farms, at two points time during transition, 1996 and 2000. In the paper they used data envelopment analysis. The results showed that livestock farms were on average, more tehnically and scale efficient than crop farms.

Hoang (2013) analyzed the productive efficiency of rice production systems in Sri Lanka. In the first stage, crop growth and economic production models were estimated to calculate three measures of productive efficiency: (1) agronomic efficiency, as the ratio of actual yield to potential yield; (2) technical efficiency (TE), as the ratio of actual yield to best practice yield; and (3) agro-economic efficiency (AgEcE), as the ratio of best practice yield to potential yield. In the second stage, TE and AgEcE were analyzed in relation to economic, institutional, social and technological factors that cause farm and spatial heterogeneity.

Results of empirical studies which analyzed efficiency of farms can provide meaningful information for farmers and policy makers to improve productive and economic performance. The inputs such as fuel, electricity, machinery, seeds, fertilizers, and chemicals significantly consume energy supplies in the production system of modern agriculture. Efficient use of these inputs helps to achieve increased production and productivity. That contributes to the economy, profitability, and competitiveness of producers (Sahabi, Feizi, Amirmoradi, 2013). 
When measuring the economic viability of farms some of the following indicators are used: the entrepreneurial profit, operating profit margin, net farm income, productivity, competitiveness, market position, rate depending on household income from non-agricultural activities, the rate indebtedness etc (Popovic, Knezevic, Tosin, 2011). When looking at the production of field crops, economic efficiency is evaluated on the basis of the achieved yields and prices of goods on the one side, and manufacturing costs on the other. Economic efficiency of production of field crops are often evaluated on the basis of gross-margin. The value of the gross margin varies from farm to farm, depending on the yield, market prices, sales method, field crops, the variable costs and the size of the farm (Jankovic et al., 2013).

\section{Materials and methods}

The survey was conducted in the region Serbia North, for 2015/2016 production year. The study included six farms, where types of small, middle and big farms are presented by two farms each. In the paper as a instrument we used a questionnaire designed for the purpose of research. The questionnaire was drawn up on the basis of literature and previous research.

The first part of the questionnaire includes identification questions (registration on farm, tax amount, age of the manager, education, successor of the farm, number of active members in the production). The second part of the questionnaire includes questions related to income on farms (total used agricultural area, area under wheat, average yield, price of wheat). The third part of the questionnaire includes questions related to costs on the farms (all elements of: variable, fixed and opportunity costs).

In the paper DEA model is used to estimate productive efficiency of farms and identify efficiency determinants. DEA was developed as a mathematical programming technique for evaluating and comparing the performance of a set of decision making units (DMU's) with common inputs and outputs. Within the DEA framework a DMU is defined as an entity that converts inputs into outputs. In DEA efficiency is defined as ratio of the weighted sum of the outputs and the weighted sum of the inputs, under the constraint that efficiency can never exceed the value of 1 . The efficiency of decision making units (DMU) increases as its outputs increase or its inputs decrease (and vice versa) (Gerdessen, Pascucci, 2013).

Each wheat producing farm is treated as decision making unit (DMU) and relative efficiency is measured for them. As the relevant inputs in wheat production are chosen:

- variable cost in RSD per hectare,

- fixed cost in RSD per hectare, and

- opportunity cost in RSD per hectare. 
The group of variable costs include expenses for, namely costs of seed, fertilizers and pesticides, and contract harvesting services. Fixed costs include depreciation of farm mechanization used in wheat production and taxes. Opportunity costs include rental rates for own land, cost of family labour, interest on own operating capital, interest on the own capital invested in machinery (Milanović et al., 2017). Farm utilised land represent farm size and include own and rented agricultural land.

From outputs as relevant in wheat enterprise was chosen farmers' income and entrepreneurial profit. Farmers' income is calculated as sum between economic profit and all opportunity costs incurred in wheat production per hectare. Entrepreneurial profit is calculated as a difference between revenue in wheat enterprise and all cost incurred in wheat production per hectare, except cost of own management.

Technical efficiency is estimated, on the basis of quantities used on input side (variable, fixed and opportunity costs), and farmers' income and entrepreneurial profit on output side. In the paper input - oriented multi stage model with variable return to scale was chosen for analysis.

Table 1 presents descriptive statistics of data set for 6 wheat producing farms. High standard deviation coefficients comparing with average values indicate of wide range used inputs. In wheat production farms vary from small with 5.5 hectares to big with 80 hectares.

In the sample all farms, except one, have several smaller parcels of wheat. A couple of farms have old mechanisation, and only one farm has a contract harvest with bigger farms. On the farms usually family labour carries out the work on the farm.

Wheat producing farms, are diverse in total farm land size, ranging from small to big farms. Because of their size, their cost, farmers' income and entrepreneurial profit vary significantly. Farmers' income varied from $24,783.57$ to $44,682.34$, and entrepreneurial profit varied from 182.42 to $14,642.88$. Variable cost varied from 54,105 to 71,273 , fixed cost varied from $5,446.43$ to $13,381.25$, and opportunity cost varied from $24,420.5$ to $30,039.47$. As we can see the biggest differences are the fixed costs and entrepreneurial profit. 
Table 1. Descriptive statistics of sample

\begin{tabular}{|l|r|r|r|r|}
\hline Wheat & \multicolumn{1}{|c|}{ Average } & \multicolumn{1}{|c|}{ Min } & \multicolumn{1}{c|}{ Max } & \multicolumn{1}{c|}{ St. Dev. } \\
\hline $\begin{array}{l}\text { Farmers' income } \\
\text { (RSD/ha) }\end{array}$ & $31,109.44$ & $24,783.57$ & $44,682.34$ & $7,114.48$ \\
\hline $\begin{array}{l}\text { Entrepreneurial } \\
\text { profit (RSD/ha) }\end{array}$ & $3,339.38$ & 182.42 & $14,642.88$ & $5,742.48$ \\
\hline $\begin{array}{l}\text { Variable cost } \\
\text { (RSD/ha) }\end{array}$ & $59,815.66$ & 54,105 & 71,273 & $7,156.77$ \\
\hline $\begin{array}{l}\text { Fixed cost (RSD/ } \\
\text { ha) }\end{array}$ & $8,923.02$ & $5,446.43$ & $13,381.25$ & $2,754.46$ \\
\hline $\begin{array}{l}\text { Opportunity cost } \\
\text { (RSD/ha) }\end{array}$ & $27,770.06$ & $24,420.5$ & $30,039.47$ & $1,965.12$ \\
\hline
\end{tabular}

Source: Author's calculation

Table 2.Correlation coefficients among inputs and output

\begin{tabular}{|l|r|r|r|l|l|}
\hline & $\begin{array}{l}\text { F a r m e r s } \\
\text { income }\end{array}$ & $\begin{array}{l}\text { En trepren e u ria l } \\
\text { profit }\end{array}$ & $\begin{array}{l}\text { Va r i a b l e } \\
\text { cost }\end{array}$ & $\begin{array}{l}\text { F i x e d } \\
\text { cost }\end{array}$ & $\begin{array}{l}\text { Opportunity } \\
\text { cost }\end{array}$ \\
\hline Farmers' income & 1.00 & & & & \\
\hline Entrepreneurial profit & 0.98 & 1.00 & & & \\
\hline Variable cost & 0.00 & -0.14 & 1.00 & & \\
\hline Fixed cost & 0.18 & 0.04 & 0.81 & 1.00 & \\
\hline Opportunity cost & 0.77 & 0.61 & 0.42 & 0.53 & 1.00 \\
\hline
\end{tabular}

Source: Author's calculation

The correlation analysis results are presented in Table 2. The application of DEA method presumes relation among inputs and outputs. The correlation coefficients between selected two outputs and three inputs are ranged from weak to strong.

\section{Results}

The computer program DEAP version 2.1. was used to analyse relative efficiency in sample of wheat producing farms in Serbia in 2015/2016 production year. For analysis input - oriented multi stage model with variable return to scale was chosen. The results of CRS and VRS DEA models presents TE and PTE respectively. Scale efficiency is the ratio of TE and PTE. Farm is scale efficient if ratio is equal to 1, otherwise if ratio is lower than 1 farm is scale inefficiency.

The results of DEA models are presented in Table 3. The average efficiency for whole sample of 6 farms was 0.77 , and only 1 farm achieved technical efficiency score of 1 . Besides technically efficient farms, 3 farms had pure technical efficiency indicating its disadvantageous conditions with size of business i.e. low scale efficiency. The technical efficiency varied from 0.677 to 1 with standard deviation of 0.126 . 
Table 3. Average efficiency of wheat producing farms

\begin{tabular}{|l|r|r|r|r|}
\hline & \multicolumn{1}{|c|}{ Average } & SD & \multicolumn{1}{|c|}{ Min } & Max \\
\hline $\begin{array}{l}\text { T e c h n i c a l } \\
\text { efficiency }\end{array}$ & 0.770 & 0.126 & 0.677 & 1 \\
\hline $\begin{array}{l}\text { Pure technical } \\
\text { efficiency }\end{array}$ & 0.965 & 0.045 & 0.888 & 1 \\
\hline Scale efficiency & 0.797 & 0.114 & 0.677 & 1 \\
\hline
\end{tabular}

Source: Data obtained from DEA analysis

In the sample increasing return to scale (IRS) dominate, since TE/PTE $<1$. That implies that wheat producing farms are technically inefficient because of scale inefficiency. Farms that are inefficient could increase efficiency by increasing arable land area and by the investments in machinery.

Graph 1. Efficiency score distribution of wheat producers by farm size in ha UAA

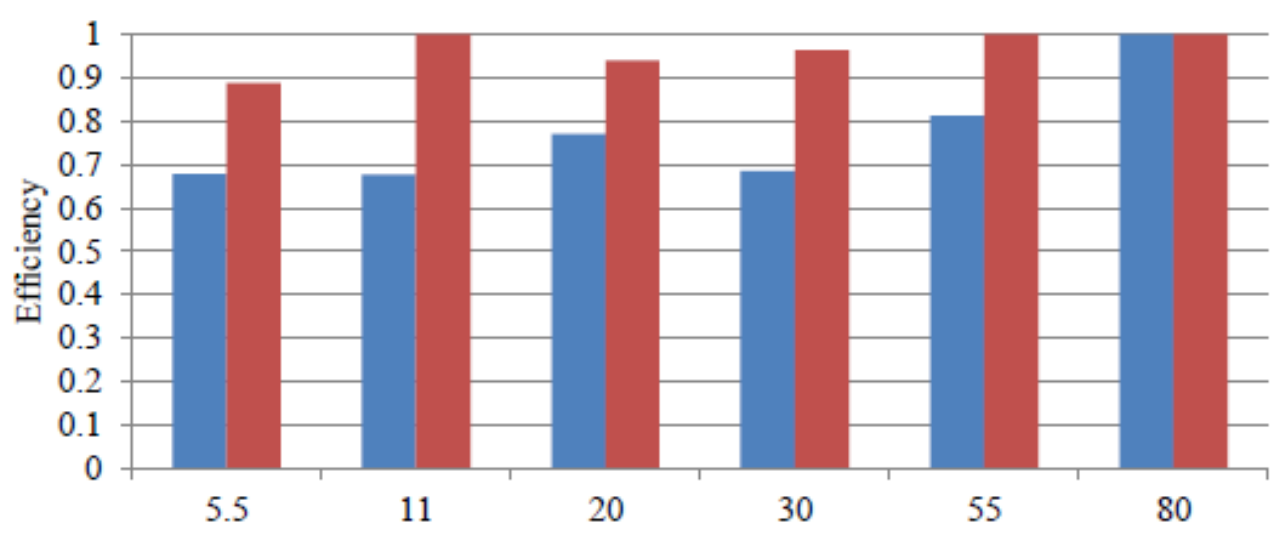

Farm used agricultural area

\section{Technical efficiency $\quad$ Pure technical efficiency}

Source: Data obtained from DEA analysis based on variables from 6 farms and its wheat enterprise budgets.

Efficiency score distribution presented in Graph 1., revealed that, from analysed 6 farms, 3 of them had PTE score of 1, while only 1 farm scored TE with value 1. Efficient farms exist in all range of farm size, measured in utilized agricultural area (UAA).

Farm which had the best results, i.e. PTE and TE efficient, does not have a fragmented holding, it is biggest farm and the whole wheat production is performed on one parcel. Also, this farm use relatively modern machinery compared to other farms. 


\section{Conclusion}

In Serbia the production of wheat, as the most important bread grain, had negative trend in area harvested till last decade when area under wheat stabilised on 0.6 million hectares. Sowing areas of wheat slightly vary from year to year, as a result of of various factors including weather conditions in planting season, expected entrepreneurial profit, etc.

Small farms in Serbia with fragmented holdings and the existing structure of production, have high production costs and inefficient use of resources. Because of that they are unable to achieve an efficient use of land. The low level of grain yields are conditioned by a high proportion of production for their own needs, and the low level of market launch. High input prices, old machinery and decline in investment make it difficult to increase productivity and profitability in production. Large farms are more likely to opt for the application of new technologies, and they usually have higher grain yields. Low productivity in the production has a negative impact on the price competitiveness of production and brings the average agricultural producer in a difficult position in the market.

This study examines technical efficiency of 6 wheat producing farms. DEA input oriented multi stage model with variable return to scale was applied to measure relative efficiency scores. The results revealed that only 1 farm achieved technical efficiency score of 1 and 3 farms had pure technical efficiency. Farm which had the best results, does not have a fragmented holding, the whole wheat production is performed on one parcel, and the farm uses a relatively modern machinery compared to other farms.

In the sample increasing return to scale (IRS) dominate and that implies that wheat producing farms are technically inefficient because of scale inefficiency. Inefficient farmers could increase technical efficiency of their wheat production by increasing arable land area and area planted with wheat, reducing fragmentation, decreasing level of used inputs, and by investments in the new machinery.

This research had some limitations. The most of family farms in Serbia do not keep evidence, what brings wide range of challenges for researcher. DEA model have advantages over other models in micro economic analysis of efficiency, but opportunity to use bigger number of inputs and outputs in analysis is conditioned by bigger sample of DMU's.

The research opens the door for future studies examining the efficiency of other crops that are produced on farms in Serbia. Research of this kind would have a major significance for all individuals involved in the agricultural sector. Analyses of determinants of efficiency provide important information for farmers to improve their performance and for policy makers to know what policies to put in place to increase the overall efficiency of farms. 


\section{Literature}

1. Alexandratos, N. (2006): World Agriculture: towards 2030/50. interim report, FAO, pp. 1-71, Rome, Italy.

2. Coelli, T.J., Prasada, Rao D. S., O’ Donnell, J.C. \& Battese, G. E. (2005): An Introduction to Efficiency and Productivity Analysis. Second Edition, Springer Science + Business Media, Inc., New York, USA.

3. Farrell, M. J. (1957): The measurement of productive efficiency. Journal of the Royal Statistical Society, Wiley, Vol. 120, No. 3, pp. 253-290, USA.

4. Gerdessen, J.C. \& Pascucci, S. (2013): Data Envelopment Analysis of sustainability indicators of European agricultural systems at regional level. Agricultural Systems, Elsevier B.V., Vol. 118, pp. 78-90, Amsterdam, The Netherlands.

5. Hoang, VN. (2013): Analysis of productive performance of crop production systems: An integrated analytical framework. Agricultural Systems, Elsevier B.V., Vol. 116, pp. 16-24, Amsterdam, The Netherlands.

6. Janković, S., Kuzevski, J., Radišić, R., Rakić, S. i Ljiljanić, N. (2013): Economic Effects of Winter Wheat Production on Farms in the Republic of Serbia in 2006 and 2011. Ratarstvo i povrtarstvo, Institut za ratarstvo i povrtarstvo, Vol. 50, Br. 1, pp. 36-42, Novi Sad.

7. Jelić, S. i Jovanović, T. (2004): Radna snaga u poljoprivrednim gazdinstvima $u$ funkciji ruralnog razvoja Srbije. Kapital u poljoprivredi, Tematski zbornik, Ekonomski fakultet, pp. 161-167, Subotica.

8. Laturffe, L., Balcombe, K., Davidova, S. \& Zawalinska, K. (2005): Tehnical and scale efficiency of crop and livestock farms in Poland: does specialization matter? Agricultural Economics, International Association of Agricultural Economists, Wiley, Vol. 32, pp. 281-296, USA.

9. Lovre, K., Gajić M. i Kresoja M., (2011): Globalizacija i održivi razvoj poljoprivrede. Agrarna i ruralna politika u Srbiji nužnost ubrzanja reformi, Tematski zbornik, DAES - Društvo agrarnih ekonomista Srbije, pp. 1-10, Beograd.

10. Milanović, N., Andžić, S., Butulija, M. (2017): Struktura kapitala kao determinanta vrednosti preduzeća, Oditor, Vol. 3, No. 1, pp. 80-90.

11. Munćan P. Todorović, S. i Munćan M. (2014): Profitability of family farms directed at crop production. Ekonomika poljoprivrede, Institut za ekonomiku poljoprivrede, Vol. 61, No. 3, pp. 575-585, Beograd.

12. Nestorov-Bizonj, J., Kovljenić, M. i Erdelji, T. (2015): The strategy for Agriculture and Rural Development of the Republic of Serbia in the Process of its Accession to the European Union. Strategic Management, University of Novi Sad, Faculty of Economics in Subotica, Vol. 20, No 3., pp. 57-66, Subotica.

13. Popović, R., Knezević, M. i Tošin, M. (2011): Održivost poljoprivrednih gazdinstava - pristupi merenju. Ekonomika poljoprivrede, Specijalni broj-1, Održiva poljoprivreda i ruralni razvoj u funkciji ostvarivanja strateških ciljeva 
republike srbije u okviru Dunavskog regiona - razvoj lokalnih zajednica, Institut za ekonomiku poljoprivrede, pp.187-192, Banja Vrdnik, Republika Srbija.

14. Popović, R., Djokić, D. i Kleut, Ž. (2015): Efficiency improvement of soybean production in Serbia. Emerging technologies and the development of agriculture. 152nd EAAE seminar, Serbian Association of Agricultural Economists, August 30th - September 1st 2016, Novi Sad, Serbia, pp. 203-217.

15. Produktna berza Novi Sad (2016): available at: http:/www.proberza. co.rs/27-06-01-07-2016/

16. Republički zavod za statistiku (2017): Baza podataka poljoprivrede, available at: http://webrzs.stat.gov.rs

17. Reynolds, M., Foulkes, J., Furbank, R., Griffiths, S., King, J., Murchie, E., Parry, M. \& Slafer, G. (2012): Achieving yield gains in wheat. Plant, Cell and Environment, Blackwell Publishing Ltd, Vol. 35, pp.1799-1823, USA.

18. Reig-Martınez E. \& Picazo-Tadeo, A. J. (2004): Analysing farming systems with Data Envelopment Analysis: citrus farming in Spain. Agricultural Systems, Elsevier B.V., Vol. 82, pp. 17-30, Amsterdam, The Netherlands.

19. Rouse, P., Harrison, J. \& Chen, L. (2010): Data Envelopment Analysis: A Practical Tool to Measure Performance. Australian Accounting Review, Wiley, No. 53, Vol. 20 Issue 2, pp. 165-177, USA.

20. Rutten, L. (2012): Innovative agricultural finance and risk management Strengthening food production and trade in the transition region. FAO investment centre, working paper, Rome, Italy.

21. Sahabi, H., Feizi, H. \& Amirmoradi, S. (2013): Which crop production system is more efficient in energy use: wheat or barley? Environment, Development and Sustainability, Springer US, Vol. 15, Issue 3, pp. 711-721. New York, USA.

22. Shewry R. P. \& Hey J.S. (2015): The contribution of wheat to human diet and health. Food and Energy Security, John Wiley \& Sons Ltd. and the Association of Applied Biologists, 20154 (3), pp. 178-202, Lancaster Environment Centre, UK.

23. Shiferaw, B., Smale, M., Braun, H. J., Duveiller, E., Reynolds M. \& Muricho, G. (2013): Crops that feed the world 10. Past successes and future challenges to the role played by wheat in global food security. Food Security, Vol. 5, pp. 291-317, Springerlink.com

24. Speelman, S., D'Haese, M., Buysse, J. \& D'Haese, L. (2008): Measure for the efficiency of water use and its determinants, a case study of small-scale irrigation schemes in North-West Province, South Africa. Agricultural Systems, Elsevier B.V., Vol. 98, pp. 31-39, Amsterdam, The Netherlands.

25. Strategija poljoprivrede i ruralnog razvoja Republike Srbije za period 2014-2024. godine ("Sl. glasnik RS", br. 85/2014), available at: http://uap.gov.rs/wp-content/ themes/uap/STRATEGIJA\%202014-2020\%20.pdf

26. USDA (2017): World agricultural supply and demand estimates (WASDE), June 9, 2017, Washington, D.C. 


\title{
EFIKASNOST PROIZVODNJE PŠENICE U REPUBLICI SRBIJI
}

\author{
Rade Popović3, Mina Kovljenic ${ }^{4}$
}

\begin{abstract}
Apstrakt
P̌̌enica je jedna od najvažnijih žitarica $i$ smatra se prvenstveno izvorom energije (ugljenih hidrata), u ljudskoj ishrani. U Srbiji najveći broj gazdinstva se bavi biljnom proizvodnjom, a pšenica je jedan od najvažnijih useva. U radu se istražuju razlike $u$ efikasnosti proizvodnje pšenice na gazdinstvima u Srbiji sa ciljem da se identifikuju najefikasnija gazdinstva, kao i mogućnosti za dalje poboljšanje. Podaci su prikupljeni za 2015/2016 proizvodnu godinu putem upitnika tokom posete poljoprivrednih gazdinstava. U radu je korišćen neparametrijski model analize podataka (DEA) za identifikaciju razlika u efikasnosti proizvodnje pšenice između gazdinstava. Rezultati istraživanja ukazuju da na efikasnost proizvodnje p̌̌enice značajno utiču veličina poljoprivrednog gazdinstva, veličina parcele i investicije u novu mehanizaciju.
\end{abstract}

Ključne reči: p̌̌enica, gazdinstva, efikasnost, DEA

3 Vanredni profesor, dr Rade Popović, Departman za agrarnu ekonomiju i agrobiznis, Ekonomski fakultetu Subotici, Segedinski put9-11,24000 Subotica, Phone: +381638041301, E-mail: popovicr@ef.uns.ac.rs

4 Mina Kovljenić M.A., doktorant ekonomije, Ekonomski fakultet u Subotici, Segedinski put 9-11, 24000 Subotica, Phone: +381645440106, E-mail: mina.sk90@yahoo.com

EP 2017 (64) 4 (1499-1511) 
ECONOMICS OF

AGRICULTURE

\section{CONTENT}

1. Adriana Radosavac, Desimir Knežević

ECONOMIC IMPORTANCE OF USE

OF PESTICIDES IN WHEAT PRODUCTION . . . . . . . . . . . 1323

2. Berhe Gebregewergs, Muuz Hadush

DOES CLIMATE CHANGE AFFECT PRICE OF VEGETABLES:

EVIDENCE FROM TIGRAI, NORTHERN MOST ETHIOPIA. . . . .1335

3. Grujica Vico, Aleksandra Govedarica-Lučić, Zoran Rajić, Radomir Bodiroga, Ivan Mičić, Silvija Zec Sambol, Marija Mičić

MULTI ATTRIBUTE ASSESSMENT APPROACH

IN VEGETABLE PRODUCTION . . . . . . . . . . . . . . 1355

4. Igor Trandafilović, Vesna Conić, Aleksandra Blagojević

IMPACT OF DEMOGRAPHIC FACTORS ON

ENVIRONMENTALLY CONSCIOUS PURCHASE BEHAVIOUR. . .1365

5. Imre Milán Harcsa

STUDY ON THE POTENTIAL OF SUBCONTRACT

PALINKA DISTILLATION . . . . . . . . . . . . . . 1379

6. Jelena Andrašić, Vera Mirović, Nada Milenković, Branimir Kalaš, Miloš Pjanić

IMPACT OF TAKEOVER PROCESS ON EMPLOYEES -

EVIDENCE FROM FOOD, RETAIL AND FINANCIAL SECTOR . . .1393

7. Jelena Birovljev, Danilo Đokić, Bojan Matkovski, Žana Kleut

ECONOMIC PERFORMANCES OF AGRICULTURE

OF CEFTA AND FORMER CEFTA COUNTRIES . . . . . . . . . . 1413

8. Jelena Marković, Svetlana Stevović

SUSTAINABILITY OF CHEMICAL SOIL QUALITY

IN SOUTHERN MORAVA RIVER VALLEY

IN CORELLATION WITH THE FLOODING $\ldots \ldots \ldots \ldots \ldots$ 
9. Mile Peševski, Zoran Milovančević

THE CHANGES IN THE USAGE OF AGRICULTURAL LAND

IN EASTERN REGION OF REPUBLIC OF MACEDONIA

BETWEEN $1991-2030 \ldots \ldots$. . . . . . . . . . . . . . . . . . . . . . .

10. Odjuvwuederhie Emmanuel Inoni, 'Oraye Dicta Ogisi, Felix Odemero Achoja

PROFITABILITY AND TECHNICAL EFFICIENCY IN HOMESTEAD

CATFISH PRODUCTION IN DELTA STATE, NIGERIA . . . . . . . 1449

11. Olja Munitlak - Ivanović, Jovan Zubović, Petar Mitić

RELATIONSHIP BETWEEN SUSTAINABLE DEVELOPMENT AND

GREEN ECONOMY - EMPHASIS ON GREEN FINANCE

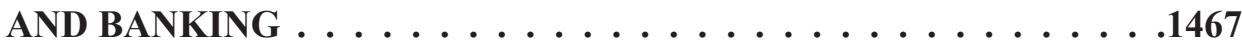

12. Petar Munćan, Dragica Božić

FARM SIZE AS A FACTOR OF EMLOYMENT AND INCOME

OF MEMBERS OF FAMILY FARMS . . . . . . . . . . . . . 1483

13. Rade Popović, Mira Kovljenić

EFFICIENCY OF WHEAT PRODUCTION ON FARMS

IN THE REPUBLIC OF SERBIA . . . . . . . . . . . . . . . . . . . . . . . . .

14. Radovan Damnjanović, Snežana Krstić, Milena Knežević, Svetislav Stanković,

Dejan Jeremić

THE DISCRIMINANT ANALYSIS APPLIED TO THE

DIFFERENTIATION OF SOIL TYPES . . . . . . . . . . . . 1513

15. Slavica Otović, Dunja Demirović, Kristina Košić, Aleksandra Vujko

FOSTERING ENTERPRENUERSHIP AT HIGH SCHOOLS:

A CASE OF RURAL AREAS IN VOJVODINA (SERBIA) . . . . . . .1523

16. Vladimir Ilić, Ivan Bauer, Anastazija Tanja Đelić, Aleksandar Nešković

INSTITUTIONAL SUPPORT FOR STRENGTHENING

ENTREPRENEURSHIP IN AGRICULTURAL PRODUCTION

OF THE REPUBLIC OF SERBIA . . . . . . . . . . . . . . . . . . . . . . . .

17. Boro Krstić, Zorica Vasiljević, Miroslav Nedeljković

INSURANCE CONTRACT AS THE BASIS FOR THE SAFETY OF

AGRICULTURAL PRODUCERS IN THE REPUBLIC OF SRPSKA • . 1555

18. Dejan Sekulić, Aleksandar Petrović, Vladimir Dimitrijević

WHO ARE WINE TOURISTS? AN EMPIRICAL INVESTIGATION

OF SEGMENTS IN SERBIAN WINE TOURISM . . . . . . . . . . . . . 
19. Milan Beslać, Ćorić Goran

FINANCIAL AND PRODUCTION ASPECTS OF GENETICALLY MODIFIED ORGANISMS $\ldots \ldots \ldots \ldots \ldots \ldots \ldots \ldots \ldots$

20. Mlađan Maksimović, Darjan Karabašević, Miodrag Brzaković, Pavle Brzaković THE EFFECTS RESULTING FROM THE APPLICATION OF THE CONCEPT OF THE SUSTAINABLE DEVELOPMENT OF RURAL TOURISM ON STARA PLANINA . . . . . . . . . . . . . . . .1595

21. Vesna Popović, Predrag Vuković, Milivoje Ćosić FOOD SAFETY AND QUALITY POLICY IN THE REPUBLIC OF SERBIA . . . . . . . . . . . . . . . . 1607

22. Radovan Pejanović, Danica Glavaš-Trbić, Mirela Tomaš-Simin PROBLEMS OF AGRICULTURAL AND RURAL DEVELOPMENT IN SERBIA AND NECESSITY OF NEW AGRICULTURAL POLICY . . . .1619

23. Saša Marković, Slavoljub Vujović, Aleksandar Damnjanović MARKETING AND HIGHER EDUCATION CONDITION IN SERBIA . . . . . . . . . . . . . . . . 1635

24. Semir Vehapi, Marina Milanović THE EFFECT OF MARKET ORIENTATION ON BUSINESS PERFORMANCE OF SERBIAN ORGANIC PRODUCERS . . . . . 1651

25. Suad Bećirović, Šemsudin Plojović, Enis Ujkanović, Senadin Plojović CHALLENGES AT STARTING AN AGRIBUSINESS IN THE HILLY MOUNTAINOUS REGIONS OF SOUTHWEST SERBIA . . . . . . . .1669

26. Vladimir Zakić, Vlado Kovačević, Jelena Damnjanović SIGNIFICANCE OF FINACIAL LITERACY FOR THE AGRICULTURAL HOLDINGS IN SERBIA . . . . . . . . . . 1687

27. Željko Bjelajac, Marijana Dukić Mijatović, Željko Vojinović PROTECTION OF LAND IN THE REPUBLIC OF SERBIA AND ECOLOGICAL SECURITY WITH REGARD TO STRATEGIC AND LEGAL FRAMEWORKS . . . . . . . . . .1703 